\title{
Comparing school mathematics curriculum between Switzerland and Indonesia
}

\author{
Vita Istihapsari ${ }^{1,2}{ }^{*}$, Iwan Junaedi², Mulyono \\ 1Universitas Ahmad Dahlan, Jl. Jend. Ahmad Yani, Tamanan, Bantul, DIY 55711, Indonesia \\ 2Universitas Negeri Semarang, Jl. Kelud Utara III, Semarang, 50237, Indonesia \\ *Corresponding e-mail: vita.istihapsari@pmat.uad.ac.id
}

\section{Article History}

Received 17 July 2021

Revised 22 November 2021

Accepted 22 November 2021

\section{Keywords}

Curriculum benchmarking;

School mathematics;

Switzerland curriculum.

How to cite this article:

Istihapsari, V., Junaedi, I., \&

Mulyono. (2021). Comparing school mathematics curriculum between Switzerland and Indonesia. Bulletin of Applied Mathematics and Mathematics Education, 1(2), 105-112.
Comparing a curriculum with the other more developed countries is essential for benchmarking the quality of education in the country. Switzerland deserves to be the object of comparison with the world's second-ranked Human Development Index. This article aims to compare the current curriculum in Indonesia, namely the 2013 curriculum, with the current curriculum in Switzerland, especially on school mathematics. The focus of the comparison lies in (1) school mathematics curriculum and (2) school mathematics content. This research is a qualitative research type of library research. We conducted a literature study, paid attention to the relevance of the literature, and analyzed it using data presentation, data reduction, and concluding. The results showed that with the education system in Switzerland, which emphasizes vocational education, the school mathematics curriculum places more emphasis on problem-solving. The contents are numbers, algebra, geometry, probability and statistics, changes and relationships, and problem-solving. Meanwhile, in Indonesia, the school mathematics curriculum is designed for every level of education with problem-based learning, project-based learning, and discovery learning models. School mathematics content includes numbers, algebra, geometry, relations and functions, statistics, and probability.

This is an open-access article under the CC-BY-SA license.

\section{Introduction}

A curriculum is an essential tool that determines a nation's development (Azis, 2018; Elisa, 2018). The curriculum provides detailed guidelines regarding the educational goals, the content and material of the lessons, and how to teach them for students at a certain level (MOEC, 2003). Therefore, in Indonesia, the Ministry of Education and Culture issues a set of ministerial regulations that regulate educational implementation standards, such as Graduate Competency Standards, Content Standards, Learning Process Standards, Assessment Standards, and Infrastructure Standards.

The position of the curriculum, which is very crucial for the national interest, makes the curriculum a guide that must be prepared very carefully and pays attention to various foundations, 
such as the ideology of Pancasila, social conditions, to the development of science and technology. One aspect that also influences curriculum development is the quality of Indonesian human resources, which must be competitive, one of which is the readiness to face globalization within the ASEAN Economic Community (Wuryandani, 2014).

Globalization forces all sectors to fulfill human needs to innovate in creating affordable and practical resources. It makes goods and services supply to become competitive. People will tend to choose a lower price from two products with the same quality (Oktaviana et al., 2019). In addition, people are only willing to pay more if the product is of a quality that other similar products do not have. This phenomenon also occurs in the fulfillment of labor needs.

Countries with superior human resources are more absorbed in more profitable sectors both domestically and abroad. On the other hand, human resources that are less superior, less educated, or less trained will tend to fill sectors easily replaced by technology. Many types of work are currently starting to be shifted by machine automation in various factories and by artificial intelligence (Ratnaya, 2011; Arief \& Saputra, 2019; Purwandini \& Irwansyah, 2018). Therefore, education is an essential effort in creating superior human resources to meet future human needs and anticipating the demographic bonus that must be useful in boosting the country's economy.

To determine how far a government needs to develop its curriculum, they can look inside and have to do benchmarking, namely looking at the condition of education abroad to reflect on whether the condition of education in the country can compete or is still lagging. Benchmarking is an unavoidable process considering that the Republic of Indonesia is an open and competitive country with other countries. Some of the benefits of benchmarking are seeing the quality of education in the country objectively and its impact on resource competition in meeting domestic needs.

Currently, the Indonesian government has made efforts to look at the results of various international assessments of the abilities of Indonesian students compared to member countries of the Organization for Economic Cooperation and Development (OECD). These assessments include the Program for International Student Assessment (PISA) and Trends in International Mathematics and Science Study (TIMSS). The Indonesian government makes the PISA and TIMSS result in an external challenge that must be followed by implementing the 2013 Curriculum (MOEC, 2018).

PISA, for example, is an international assessment of the ability of 15-year-old students in math, reading, and science literacy (OECD, 2018). Indonesia has participated in the assessment since 2001. In 2018, 12,098 students from 399 schools took the test. As a result, Indonesia scored 379 in mathematical literacy, compared to an average score of 489 for students in OECD countries. Furthermore, only $28 \%$ of Indonesian students were able to work on Level 2 math problems or higher. Problems at Level 2 ask students to recognize or interpret simple situations in various forms of mathematical representation. That is, the remaining 78\% cannot exceed Level 2 questions.

Although benchmarking efforts have been carried out by looking at the results of international assessments, the benchmarking is only limited to comparing educational outcomes, not the process or content of learning. Therefore, it is necessary to make a more comprehensive comparison of the curriculum profile between the 2013 Curriculum applicable in Indonesia and the curriculum in countries considered more advanced. In this case, we can look at Switzerland as a reference.

Switzerland (See Figure 1) is a country in the European Region home to 7.5 million people divided into three regions based on the language used, namely the German-speaking, Frenchspeaking, and Italian-speaking areas (Meyer, 2009). Swiss citizens are required to complete up to nine years of education. The uniqueness of education in Switzerland lies in its educational focus on vocational education and training. With a Human Development Index of 0.946, the second-highest 
in the world, a life expectancy of 83.6 years, and a per capita income of USD 59,375 (UNDP, 2020), Switzerland deserves to be used a benchmark for educational curriculum, especially in the field of mathematics education.

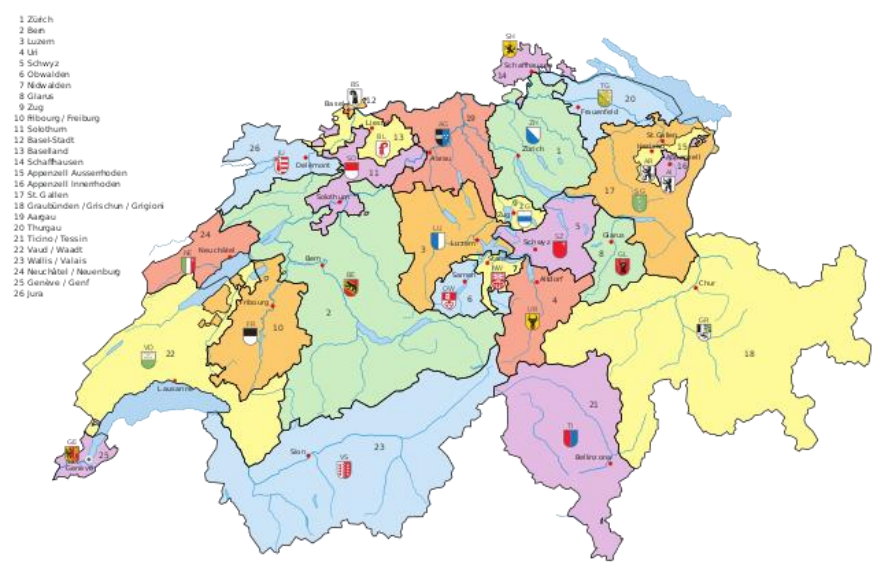

Figure 1. Switzerland (Karza, 2008).

This article aims to compare the current curriculum in Indonesia, namely the 2013 curriculum, with the current curriculum in Switzerland, especially on school mathematics. The focus of the comparison lies in (1) school mathematics curriculum and (2) school mathematics content.

\section{Method}

This research is a qualitative research type of library research. The subject studied is literature that discusses the school mathematics curriculum both in Switzerland and in Indonesia. The data collection method used is the literature study method. The researcher collected literature through Google Scholar with the keywords "education system in Switzerland," "mathematics education in Switzerland," and "Switzerland education system in mathematics." From the search, we obtained 1,000 articles listed in 10 pages. Meanwhile, we got the literature about the Indonesian 2013 curriculum from the Ministry of Education and Culture regulations.

Furthermore, to maintain the validity of data sources, from the entire list of references found from search results on Google Scholar, researchers filtered only sources published in the last two years (since 2020). It is intended to ensure that the reference examines the current state of mathematics education in Switzerland. From the screening results, we still chose sources from scientific journals so that in the end, six reference documents were obtained that describe the implementation of mathematics learning in Switzerland (Gasteiger et al., 2021; Clivaz \& Miyakawa, 2020; Merki et al., 2021; Tomasik et al., 2020; Bose, 2020; Deissinger \& Gonon, 2021), two additional references from outside this period but with topics that are still relevant (Marty et al., 2018; Meyer, 2009), as well as one policy reference education system in Switzerland on the website of the State Secretariat for Education Research and Innovation (SERI, 2021). As for the literature sourced from the ministerial regulatory documents that regulate the implementation of the 2013 Curriculum, the researchers limit them to regulatory documents that are still valid.

The data was then analyzed using the stages according to Miles and Huberman (1994), which consisted of data presentation, data reduction, and concluding. 


\section{Results and Discussion}

\section{School Mathematics Curriculum}

\section{Switzerland}

The education system in Switzerland provides for nine years of compulsory education at the primary and junior secondary levels. After that, education in Switzerland is divided into two, namely vocational education and general education (SERI, 2021). The peculiarity of education in Switzerland lies in the government's attention to vocational education. Approximately $70 \%$ of students who graduate from junior high school choose to enter vocational education and training. The scheme taken is dual education, where learning combines activities at school and activities in companies (SERI, 2021). The education roadmap in Switzerland is shown in Figure 2 (SERI, 2021). This map also has not changed much from the 2006 roadmap (Meyer, 2009). Figure 2 shows the dominance of vocational education in Switzerland, which brings schools closer to the business and industry.

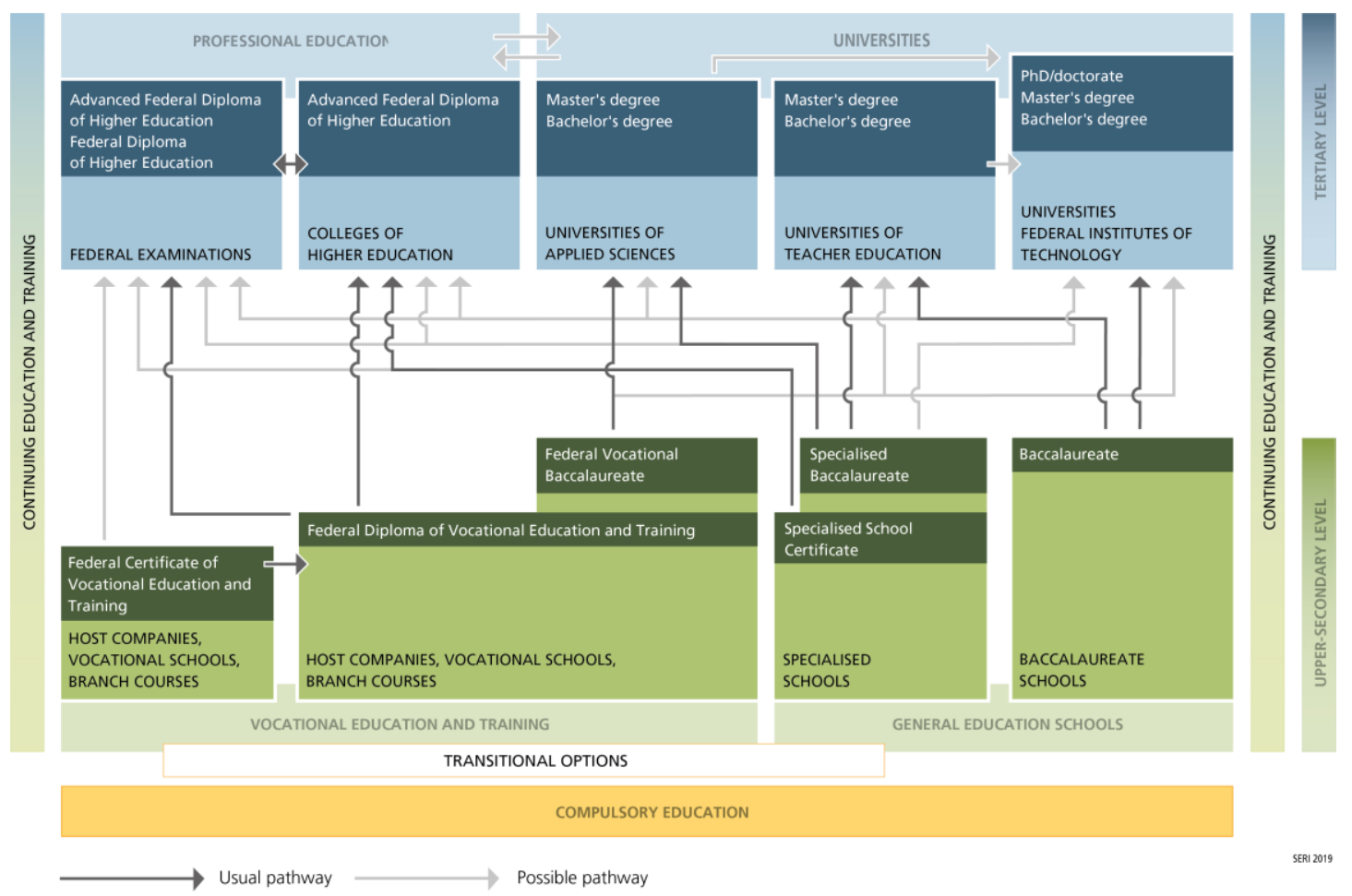

Figure 2. A roadmap of the education that students take in Switzerland

The curriculum in Switzerland introduces mathematics from kindergarten age. However, there is no stipulation on the length of time for teaching mathematics per week (Gasteiger et al., 2021). While at the basic education level, for example, in Grade 4, one learning meeting is held for 65 minutes (Clivaz \& Miyakawa, 2020), as shown in Figure 3.

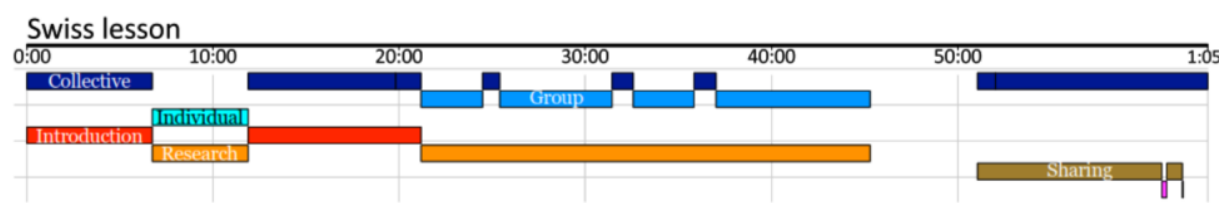

Figure 3. The structure of mathematics for Grade 4 in Switzerland 
Figure 3 shows that learning begins with a classical opening inserted by an individual investigation of a problem. Next, a group investigation session and a classical sharing session were conducted. Furthermore, education in Switzerland mandates teachers to continue to encourage intelligent students and less intelligent students together (Merki et al., 2021).

Mathematics lesson plans (RPP) in Switzerland generally contain (1) details of the material, learning objectives, observation instructions, teacher and student learning steps, and what plans will be written on the blackboard (Clivaz \& Miyakawa, 2020). As for textbooks, uniquely, books in Switzerland emphasize problem-solving but are not associated with information that problemsolving is related to certain mathematical concepts. The purpose of problem-solving is solely to get a solution; there is no explicit synthesis process. From these problem-solving activities, students can understand certain mathematical concepts (Clivaz \& Miyakawa, 2020).

\section{Indonesia}

The education system in Indonesia recognizes nine years of compulsory education based on the National Education System Law (MOEC, 2003). However, the 12-year compulsory education program to senior secondary education has been included in the education roadmap in 2021. The promotion of vocational education is also carried out massively, but the portion is still balanced between high school students (4.7 million) and vocational students (4.9 million) (MOEC, 2021).

In the 2013 Curriculum, mathematics is taught from early childhood education according to their cognitive development. Mathematics is taught for 4 to 5 hours of lessons a week with a duration of one hour of lessons equivalent to 35 minutes for elementary schools, 40 minutes for junior high schools, and 45 minutes for senior high schools (MOEC, 2018a). Usually, one meeting is 2 hours long.

Based on the Standard Learning Process, each learning meeting contains preliminary activities that include preparation, apperception, and motivation; core activities that contain the syntax of the learning model used; and closing activities that contain conclusions and reflections (MOEC, 2016). The document states that the recommended learning models include problem-based learning, project-based learning, and discovery learning. The RPP structure in Indonesia is recommended to contain identity, essential competencies and indicators of achievement, learning objectives, materials, learning models and methods used, learning steps, media and learning resources, and assessment methods. The government provides nationally applicable textbooks containing materials and how to teach them (teacher books and student books).

\section{School Mathematics Content}

\section{Switzerland}

Mathematics materials taught in kindergarten include numbering, comparison, time, and geometry (Gasteiger et al., 2021). At a higher level, the content of mathematical material is more integrated with problem-solving. All problem-solving-based learning begins with the teacher giving an open problem (Clivaz \& Miyakawa, 2020). It is reinforced by the opinion of Bose (2020) that applied mathematics materials related to everyday life have been used since the elementary school level. Another material is numbers, the decimal system, and standard sizes. Applied mathematics material is taught from an early age to the high school level according to the studied context (Deissinger \& Gonon, 2021).

Details of the content of mathematics taught at the primary and secondary education levels are shown in Table 1. 
Table 1. Mathematics content

\begin{tabular}{|c|c|}
\hline Theory & Description \\
\hline \multirow[t]{5}{*}{ Number } & This material includes: \\
\hline & 1. Real numbers, their properties, and their use in everyday life. \\
\hline & 2. The system from natural numbers to real numbers. \\
\hline & 3. Fractions and decimals, estimation. \\
\hline & $\begin{array}{l}\text { 4. Assessment of the fairness of the results of estimates and calculations } \\
\text { in the context of daily life. }\end{array}$ \\
\hline \multirow[t]{5}{*}{ Algebra } & This material includes: \\
\hline & $\begin{array}{l}\text { 1. The meaning of the concept of variables, algebraic expressions, and } \\
\text { equations in situations relevant to students. }\end{array}$ \\
\hline & 2. Method of solving algebraic problem equations. \\
\hline & 3. Number sequence pattern. \\
\hline & 4. Algorithm programming. \\
\hline \multirow[t]{5}{*}{ Geometry } & This material includes: \\
\hline & 1. Geometric objects and their relationship to objects. \\
\hline & $\begin{array}{l}\text { 2. Imaging and construction of geometric objects, both with and without } \\
\text { digital tools. Scale when zooming in and out on two- and three- } \\
\text { dimensional objects. }\end{array}$ \\
\hline & $\begin{array}{l}\text { 3. Congruence and symmetry in the plane. A method for calculating the } \\
\text { area, perimeter, and volume of geometric objects. }\end{array}$ \\
\hline & $\begin{array}{l}\text { 4. Geometric theorems and formulas and the need for argumentation } \\
\text { for their validity. }\end{array}$ \\
\hline Odds and & This material includes: \\
\hline \multirow[t]{4}{*}{ Statistics } & 1. Opportunities in everyday life. \\
\hline & 2. Combinatorial principles in everyday life and simple math problems. \\
\hline & $\begin{array}{l}\text { 3. Tables, diagrams, and graphs and their interpretations to illustrate } \\
\text { survey results both with and without digital tools, center measures, } \\
\text { and dispersion measures. }\end{array}$ \\
\hline & $\begin{array}{l}\text { 4. Assessment of risks and opportunities based on computer } \\
\text { simulations and statistical materials. }\end{array}$ \\
\hline \multirow{3}{*}{$\begin{array}{l}\text { Relationships } \\
\text { and Change }\end{array}$} & This material includes: \\
\hline & $\begin{array}{l}\text { 1. Percent to express change, calculation by percent in everyday } \\
\text { situations, and different fields of study. }\end{array}$ \\
\hline & $\begin{array}{l}\text { 2. Functions and equations of straight lines, with or without digital } \\
\text { tools. }\end{array}$ \\
\hline Problem & This material includes: \\
\hline \multirow[t]{4}{*}{ Solving } & $\begin{array}{l}\text { 1. Strategies for problem-solving in everyday situations and different } \\
\text { fields of study and evaluation of selected strategies and methods. }\end{array}$ \\
\hline & $\begin{array}{l}\text { 2. The mathematical formulation of questions based on everyday } \\
\text { situations. }\end{array}$ \\
\hline & 3. Simple mathematical model. \\
\hline & 4. Programming algorithms for solving mathematical problems. \\
\hline
\end{tabular}


Indonesia

Mathematical material is taught according to the students' thinking stages. At the kindergarten level, students generally begin to be introduced to numbers and numbers. Furthermore, at the primary and secondary education levels, ministerial regulations regulate core competencies and basic competencies that must be taught at certain levels (MOEC, 2018b). In general, mathematics content includes numbers, algebra, geometry, relations and functions, statistics, and probability. Furthermore, Indonesian MOEC demands the mathematics learning implemented using various contexts. Many contexts could be explored for mathematics learning, such as culture (Prahmana et al., 2021), children's games (Ulya et al., 2017), personal, occupational, society, and sciences (OECD, 2018).

\section{Conclusion}

The school mathematics curriculum in Switzerland is designed to support its vocational education-centered education system. Mathematics has been introduced since the kindergarten level and continued in primary and secondary education in problem-solving. The focus of problemsolving is more on solving the problem, not on the synthesis of mathematical concepts obtained from solving the problem. It is a consequence of the vocational education paradigm that brings school mathematics material closer to real problems in everyday life and other fields. The contents are numbers, algebra, geometry, probability and statistics, changes and relationships, and problemsolving.

The school mathematics curriculum in Indonesia refers to the Indonesian Ministry of Education and Culture standards. Mathematics is taught at all levels of education with material complexity, from simple to complex based on cognitive development. Problem-based learning is one of the recommended learning models but emphasizes what concepts are understood or found after solving problems. Other learning models are project-based learning and discovery learning. School mathematics content includes numbers, algebra, geometry, relations and functions, statistics, and probability.

\section{References}

Arief, N. N., \& Saputra, M. A. A. (2019). Kompetensi baru public relations (PR) pada era artificial intelligence. Jurnal Sistem Cerdas, 2(1), 1-12.

Azis, R. (2018). Implementasi pengembangan kurikulum. Jurnal Inspiratif Pendidikan, 7(1), 44-50.

Bose, L. (2020). Nations and numbers: Elementary mathematics education as a nationalizing tool. Croatian Journal of Education: Hrvatski časopis za odgoj i obrazovanje, 22(Sp. Ed. 2), 47-63.

Clivaz, S., \& Miyakawa, T. (2020). The effects of culture on mathematics lessons: An international comparative study of a collaboratively designed lesson.Educational Studies in Mathematics, 105(1), 53-70.

Deissinger, T., \& Gonon, P. (2021). The development and cultural foundations of dual apprenticeships-a comparison of Germany and Switzerland. Journal of Vocational Education \& Training, 73(2), 197-216.

Elisa, E. (2018). Pengertian, peranan, dan fungsi kurikulum. Jurnal Curere, 1(2), 1-12.

Gasteiger, H., Brunner, E., \& Chen, C. S. (2021). Basic conditions of early mathematics education-A comparison between Germany, Taiwan and Switzerland. International Journal of Science and Mathematics Education, 19(1), 111-127.

Karza. (2008). Vectormap of Switzerland with all canton, names and flags as separated layers. Available at: https://commons.wikimedia.org/w/index.php?curid=5412012.

Marty, L., Venturini, P., \& Almqvist, J. (2018). Teaching traditions in science education in Switzerland, Sweden and France: A comparative analysis of three curricula. European Educational Research Journal, 17(1), 51-70. 
Merki, K. M., Buehlmann, F., Kamm, C., Truniger, A., \& Emmerich, M. (2021). Support of students in primary schools: a comparative case study in a selective education system. Journal of Curriculum Studies, 53(3), 279-297.

Meyer, T. (2009). Can "vocationalisation" of education go too far? The case of Switzerland. European Journal of Vocational Training, 46(1), 28-40.

Miles, M. B., \& Huberman, A. M. (1994). Qualitative data analysis: An expanded sourcebook. Sage Publishing.

MOEC. (2003). Undang-Undang RI Nomor 20 Tahun 2003 tentang Sistem Pendidikan Nasional. Available at: https://pmpk.kemdikbud.go.id/assets/docs/UU_2003_No_20__Sistem_Pendidikan_Nasional.pdf.

MOEC. (2016). Peraturan Menteri Pendidikan dan Kebudayaan RI Nomor 22 Tahun 2016 tentang Standar Proses Pembelajaran Jenjang Pendidikan Dasar dan Menengah. Available at: https://bsnp-indonesia.org/wpcontent/uploads/2009/06/Permendikbud_Tahun2016_Nomor022_Lampiran.pdf.

MOEC (2018a). Peraturan Menteri Pendidikan dan Kebudayaan RI Nomor 35 Tahun 2018 tentang Perubahan Permendikbud Nomor 58 Tahun 2014 tentang Kurikulum 2013 untuk Jenjang Pendidikan Dasar dan Menengah. Available at: https://pusmenjar.kemdikbud.go.id/download/file-71.

MOEC. (2018b). Peraturan Menteri Pendidikan dan Kebudayaan RI Nomor 37 Tahun 2018 tentang Perubahan Permendikbud Nomor 24 Tahun 2016 tentang Kompetensi Inti dan Kompetensi Dasar untuk Jenjang Pendidikan Dasar dan Menengah. Available at: https://jdih.kemdikbud.go.id/arsip/Permendikbud\%20Nomor\%2037\%20Tahun\%202018.pd f.

MOEC. (2021). Statistik pendidikan SMA dan SMK di Indonesia. Available at: http://statistik.data.kemdikbud.go.id/index.php/page/sma.

Octaviana, T., Mawahib, M. M., \& Taufik, A. (2019). Analisis strategi penjualan barang komoditas di swalayan surya gondang perspektif hukum ekonomi syariah. Qawãnïn: Journal of Economic Syaria Law, 3(2), 163-181.

OECD. (2018). Program for International Student Assessment 2018 Country Note: Indonesia. Available at: https://www.oecd.org/pisa/publications/PISA2018_CN_IDN.pdf.

Prahmana, R. C. I., \& Istiandaru, A. (2021). Learning sets theory using shadow puppet: A study of Javanese ethnomathematics. Mathematics, 9(22), 2938.

Purwandini, D. A., \& Irwansyah, I. (2018). Komunikasi korporasi pada era Industri 4.0. Jurnal Ilmu Sosial, 17(1), 53-63.

Ratnaya, I. G. (2011). Dampak negatif perkembangan teknologi informatika dan komunikasi dan cara antisifasinya. Jurnal Pendidikan Teknologi Dan Kejuruan, 8(1).

Tomasik, M. J., Helbling, L. A., \& Moser, U. (2020). Educational gains of in-person vs. distance learning in primary and secondary schools: A natural experiment during the COVID-19 pandemic school closures in Switzerland. International Journal of Psychology.

Ulya, H., \& Istiandaru, A. (2018). Permainan pasaran dalam pembelajaran matematika materi aritmetika sosial untuk menumbuhkan karakter kewirausahaan. Seminar Nasional Pendidikan Matematika Ahmad Dahlan (Vol. 1, pp. 88-93). UAD Press.

UNDP. (2020). Human development report. Available at: https://web.archive.org/web/20200430080741/http://hdr.undp.org/en/content/2019human-development-index-ranking.

Wuryandani, D. (2014). Peluang dan tantangan SDM Indonesia menyongsong era masyarakat ekonomi ASEAN. Info Singkat Ekonomi dan Kebijakan Publik, 6(17), 13-16. 